\title{
Stakeholders' involvement in service delivery at eDumbe Municipality
}

\begin{tabular}{|c|c|}
\hline $\begin{array}{l}\text { Authors: } \\
\text { Zweliknona Z } \\
\text { Noluthando S }\end{array}$ & $\begin{array}{l}\text { Mane }^{1} \text { (D) } \\
\text { Matsiliza }\end{array}$ \\
\hline $\begin{array}{l}\text { Affiliations: } \\
{ }^{1} \text { Department } \\
\text { Management, } \\
\text { Law, Faculty o } \\
\text { Sciences, Durk } \\
\text { Technology, Pi } \\
\text { South Africa }\end{array}$ & $\begin{array}{l}\text { f Public } \\
\text { Economics and } \\
\text { Management } \\
\text { an University of } \\
\text { etermaritzburg, }\end{array}$ \\
\hline $\begin{array}{l}{ }^{2} \text { Department } \\
\text { Administratio } \\
\text { Hospitality M } \\
\text { Faculty of Con } \\
\text { Management, } \\
\text { Walter Sisulu } \\
\text { Mthatha, Sou }\end{array}$ & $\begin{array}{l}\text { f Public } \\
\text { and } \\
\text { anagement, } \\
\text { amerce and } \\
\text { NMD Campus, } \\
\text { Jniversity, } \\
\text { h Africa }\end{array}$ \\
\hline $\begin{array}{l}\text { Correspondin } \\
\text { Noluthando N } \\
\text { nmatsiliza@w }\end{array}$ & $\begin{array}{l}\text { g author: } \\
\text { latsiliza, } \\
\text { su.ac.za }\end{array}$ \\
\hline $\begin{array}{l}\text { Dates: } \\
\text { Received: } 30 \\
\text { Accepted: } 17 \\
\text { Published: } 28\end{array}$ & $\begin{array}{l}\text { ept. } 2021 \\
\text { Nov. } 2021 \\
\text { Feb. } 2022\end{array}$ \\
\hline $\begin{array}{l}\text { How to cite th } \\
\text { Zwane, Z. \& N } \\
\text { 2022, 'Stakeh } \\
\text { involvement i } \\
\text { delivery at eD } \\
\text { Municipality', } \\
\text { Government } \\
\text { Innovation 3(C } \\
\text { doi.org/10.41 }\end{array}$ & $\begin{array}{l}\text { is article: } \\
\text { atsiliza, N.S., } \\
\text { olders' } \\
\text { service } \\
\text { umbe } \\
\text { Journal of Local } \\
\text { esearch and } \\
\text { ), a45. https:// } \\
2 \text { 2/jolgri.v3i0.45 }\end{array}$ \\
\hline $\begin{array}{l}\text { Copyright: } \\
\text { (C) 2022. The } \\
\text { Licensee: AOS } \\
\text { is licensed un } \\
\text { Creative Com } \\
\text { Attribution Lic }\end{array}$ & $\begin{array}{l}\text { uthors. } \\
\text { IS. This work } \\
\text { ler the } \\
\text { nons } \\
\text { ense. }\end{array}$ \\
\hline Read online: & \\
\hline 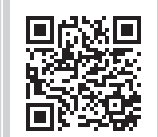 & $\begin{array}{l}\text { Scan this QR } \\
\text { code with your } \\
\text { smart phone or } \\
\text { mobile device } \\
\text { to read online. }\end{array}$ \\
\hline
\end{tabular}

Background: Stakeholders have diverse interests in the provision of public services; hence, they support municipalities in responding to communities' basic needs by engaging them in decision-making and in offering development support.

Aim: This article aims at assessing stakeholders' engagement in service provision at eDumbe Municipality, in Kwazulu-Natal. The main objective was to improve service provision and development at eDumbe local area.

Setting: eDumbe municipal area is the study location where data were collected by researchers.

Methods: A qualitative approach was employed to collect and analyse data, using the case study design.

Results: It has emerged that resource management, socio-economic factors and governance issues are barriers in successfully achieving stakeholders' full support in service delivery.

Conclusion: This study demonstrated dynamics of limited stakeholders' engagement at eDumbe. It is recommended that municipality must improve its relations and strategies for engaging stakeholders to improve their participation in service provision. Findings from this study contribute to the existing knowledge of participatory democracy in South Africa.

Keywords: community engagement; efficiency; service delivery; stakeholder participation; sustainability.

\section{Introduction}

Using a participatory democracy framework, this study assesses the involvement of stakeholders in service delivery at the eDumbe Municipality. This article argues that the interests of stakeholders have been overlooked by municipal officials of eDumbe. The current local government environment is volatile, and municipalities must adapt to constant environmental changes. The principles of cooperative government are provided by the constitution (1996) to be used as a mechanism that can restore peace and relations between officials and the communities. The complexity of municipalities is also exacerbated by political will that is influential on the state power use (Mohale 2017:53).

The environment of municipalities can present itself as an open and as a closed system; hence municipalities must adapt to the environment (Pasquini \& Shearing 2014). The external factors that are prominent in interacting with municipalities are economic, political, geographic and social. Moreover, the internal factors include municipal goals and strategies, expertise of municipal officials and their staff, infrastructure and financial resources. Local government must adapt to these factors in order to deliver services effectively. In contrast, community needs are more than what municipalities can offer; hence municipalities are not always successful in satisfying communities in service delivery.

The discourse of effectiveness must be understood to be linked to the environment; hence its context must be understood as cyclical and can be favourable when the environment provides the opportunity. In the post-New Public Management (NPM) system, governments are subjected to scrutiny by communities and are held accountable for their doings. Hence, the work of public officials is complex and complicated. The issue of networks is crucial for municipalities to maintain vertical governance relations between them and stakeholders and between them and the provincial and national governments. 
Municipalities can fulfil their political mandate by communicating, collaborating and allowing stakeholders to participate fully in decision making relating to their needs and demands. Venter (Van der Waldt 2014:88) is of the view that public service delivery can be realised when there is active participation by all actors in decision-making regarding service delivery. This article responds to the research aim by focussing on the problem statement, theoretical framework, literature review, research methodology, findings and interpretation, conclusion and recommendations.

\section{Problem statement}

The aim of this article is to assess stakeholders' engagement in service provision at eDumbe Municipality, in KwazuluNatal. The apartheid geographic design and planning of municipalities brought a legacy of challenges that discourage citizens in municipalities to effect sustainable operations and service provision (Masuku \& Jili 2019). Furthermore, the non-payment of user charges and rates by citizens demonstrate that the user pay principle is not legitimate to its users in small- and medium-sized municipalities that do not have a strong financial base and autonomy in decisionmaking during policy formulation (Fuo, 2017). Scholars echoed the non-compliance with policy directives by municipalities as emanating from a lack of support from the central government (Khaile, Davids \& Khaile 2021; Ledger 2020). Previously 'homestead' and 'bantustan' areas missed the opportunity to development and upgrade their infrastructure that would allow the service provision of machinery and achieve effective service delivery. The recent mass demonstrations and service delivery boycotts demonstrate the dissatisfaction of the community towards municipalities (Mabizela \& Matsiliza 2020). Unexpectedly, service delivery boycotts continued after 1994, particularly at the eDumbe Municipality, where residents realised that the municipal agenda to develop communities was a ploy for the political manifesto that outlined promises of greener pastures that never materialised post-1996 (Zwane 2017).

This was further exacerbated by the political instability and administrative incapacity to render services to the community of eDumbe. The series of social protests at eDumbe were instigated by the lack of capacity of municipal officials and poor infrastructure needed to support service delivery. There are also gaps in decision-making because of the lack of involvement of community members in resource planning and participatory budgeting; hence, managing municipal operations was new to both parties under a new dispensation. Zwane (2017:3) asserted that municipal services are strained by a lack of resources, especially financial and human resources.

\section{Literature review \\ Theoretical approach}

This article adopted the participatory development approach to understand the urgency for effective public participation in local government.

\section{Participatory democracy}

Participatory democracy or participative democracy (PD) underscores the broad spectrum of participation of the constituents in a political system that is supported by freedom and rights based political systems (Modise 2017). Participatory democracy originates from the early writings of Jean-Jacques Rousseau and later promoted by J.S. Mill and G. D. H. Cole, who posited that political participation is crucial for the fulfilment of a just society (Wolfe 1985). Furthermore, Barber (1984) and Kaufman (1960) engaged in discursive preferences of participatory democracy that demonstrate the nexus of community-based activities and democracy.

In the context of this study, PD is linked to pluralism and democracy. Pluralism advocates for the consideration of a mass voices in decision-making, and the word democracy has etymological roots from the Greek words 'demos' and 'kratos', and it implies that the majority of the people rule and are holding power (Barber 1984; Kaufman 1960). Participatory democracy supports both pluralism and freedom; hence there is affirmation of diverse political parties in South Africa considered, but also all stakeholders should be involved in public participation. In the current trend of governance, municipalities should inculcate tenets of democracy by engaging with civil society, private and non-governmental organisations to participate in decision-making regarding public issues affecting them (Escobar 2017). Liberals stress the dichotomy between civil society groups and the political realm. Some scholars argue that in a developmental state such as South Africa, government should lead development and provide basic services to all stakeholders (Mohale 2017:53). In addition, Naidoo and Ramphal (2018:8) assert that government must maintain a balance between government and stakeholders' interests by supporting all stakeholders involved in the decision-making process.

Section 12 of the South African Constitution (RSA 1996), the entrenched Bill of Rights endorses South Africa as a sovereign democratic state. Through the Constitution (1996), the parliament endorsed a people's parliament as a forum that promotes public participation by visiting all provinces to broaden democracy and public participation. The provinces and local government are mandated through delegated legislation, to comply with all the policies and law that protects citizens' rights during public participation. Unlike the apartheid government, the democratic government endorsed several policies and mechanisms such as the Reconstruction and Development Programme to transform the economy and the public service with the intention to develop the state (RDP, 1994). The Municipal Systems Act (2000) also supported municipalities in the establishment of advisory committees that can advise the council in issues of its business, including the participation of communities and other parties in issues affecting them. A case in point has been demonstrated by the local government during COVID 19 pandemic, where stakeholders such as the municipality, businesses, non-governmental organisations and civic organisations must comply with COVID-19 compliance 
during the preparation and conduct of funerals and memorial services Leadership, P. Local Government Bulletin 14.

\section{Public participation}

Some of the values that are subscribed to the notion of public participation in local government include the following:

- Human dignity and justice

Human dignity is protected in South Africa and can also be achieved by applying equality and the advancement of human rights and freedom for all (Escobar 2017:1). This implies that municipal officials must be cognisant of human rights to provide basic human needs based on the availability of resources. It is the responsibility of the government to address the imbalances of the past and target the previously discriminated group and provide basic services and other goods as part of their redressal. Through the court system, stakeholders can approach the judicial system and courts and request an amendment of a decision or policy when policymakers were treated unfairly or unjustly (Wangari 2018:5). It is therefore notable that certain values such as 'customer satisfaction' and 'Batho Pele' principles can be considered as tools to motivating workers positively in their line of duty to enable them to attainment service delivery targets. According to Ogonu, Nwokah \& Acee-Eke (2019:385), procedural justice is a democratic way of redressing the fundamental mistakes during service provision, when a negative service encounters or service failures may have resulted in defection of customers and citizens. In some instances, when the continued dissatisfaction is gross and not corrected, stakeholders may summon municipalities into protests and social riots:

\section{- Managerial accountability}

Managers must inspire subordinates by being accountable and responsive to the oversight role, policy formulation and implementation of public policy that leads to service delivery (Masuku \& Jili 2019:3). Managers are expected to account not only to their superiors but also to the public. They need to report on the manner they manage resources and how they have been responsive to the public on whether they have achieved their intended objectives. Policies such as Section 71(1) of the Municipal Finance Management Act, the Municipal Financial Management Act 2003 (Act No. 56 of 2003), are useful tools that are used to enforce the practice of financial accountability:

\section{- Management of resources}

As accounting officials, municipal managers are entrusted to manage municipality's assets, income and expenditure (RSA 1999). It is also the responsibility of stakeholders to hold the administrative officers answerable for the manner they discharge their duties. With such a limited tax base, municipalities like eDumbe neither have a strong tax base nor enough revenue to support development efforts and service delivery. In the context of development, municipalities benefit from the equitable sharing that is funded by the national government. The Integrated Development Plan (IDP) outlines and guides the planning of resources that must be spent by municipalities. Any deviation from the norm must be communicated to the communities through ward committee meetings and 'imbizo' by the mayor:

\section{- Participatory leadership}

A participatory leadership approach is suitable for driving service provision because it encourages leaders and senior management staff to ethically work together with subordinates in order to motivate them to attain goals and objectives of their units and departments inclusively with the stakeholders as planned. Leaders are tempted to pursue political interests and focus on political and administrative functions that are determined by municipal needs (Kgatle 2018). The political leadership's role is to drive the service delivery agenda of the municipality in terms of the IDP, which is in line with the district goals and the provincial and the national agenda of the government of the day. Leaders and managers must also hire suitable and capable staff that can work towards fulfilling departmental goals and the mandate of local government. It is imperative for political leadership to focus on their roles and functions and avoid too much political interference whilst participating in local affairs of their constituencies:

\section{- Sustainability of service provision}

The South African Constitution (1996) provides for the devolution of power to the local government. Hence, municipalities are supported by the national government through various grants to ensure that there is a development of service provision and infrastructure to work. Municipalities are established to develop communities in their areas of jurisdiction (Aiguosatile \& Uyi 2011:149). There is an economic problem where municipal resources are limited and cannot match the human needs and demands. Therefore, municipalities must adopt sustainability by using resources without compromising the future generation. Sustainability is new and lacks pragmatism in local government.

Municipalities are delegated by the South African Constitution of 1996 to deliver effective and efficient services to the community in a sustainable manner. Sustainable services can only be offered when resources and revenue are managed efficiently, fairly at a reasonable cost. Some municipalities are challenged by a lack of revenue and savings to invest on service provision. It seems to be an ideal to achieve efficiency in those municipalities with no source of revenue collected from taxpayers and residents, but are fully dependent on government subsidies (Adu-Gyamfi, Asongu \& Sonto 2018). During the COVID-19 lockdown restrictions, municipalities such as eDumbe struggle to collect revenue to sustain their operations financially because they collect less from the ratepayers as some have lost jobs and income to conduct their businesses. Financial sustainability can be ideal because rural municipalities such 
as eDumbe consume a low tax base and rely on equitable sharing of revenue from the national government and the Municipal Infrastructure Grant (MIG):

\section{- Internal organisational arrangements}

Municipalities can only operate well when there are internal controls and organisational arrangement that are in place to support service provision. The internal controls also need to be supported by vigorous control mechanism based on good governance and 'Batho Pele' principles to effectively improve governance and organisational arrangements. Managers and leaders have an obligation to monitor and supervise operating teams in their respective units in an organisation. It is the responsibility of heads of the department, council and ward councillors to make sure that stakeholders are updated with issues relating to service delivery to avoid protests and unfulfilled financial mandates (Fourie 2009:13):

- Benchmarking and information communication technologies

Benchmarking has a history of success in improving performance in private organisations. Benchmarking is also relevant and significant for assessing the relative historical performance of public organisations (controlling for external conditions), quantify utility progress towards meeting policy objectives, assist in the identification of performance gaps in utilities handled by specialists and enable regulators to match the targets that are desired to be met and the incentives for utilities (Mugisha et al. 2007). It is imperative that municipal employees benchmark on various strategies that can enhance stakeholders' involvement in their core business. Municipalities can also collaborate with other service providers and pilot projects benchmarked from other African countries and internationally, especially in areas such as skill development and training programmes. The intention of such projects would be to improve their skills. In return, the organisational internal arrangements can be nourished for public participation and service provision:

\section{- Adapting to environmental changes}

Service delivery is performed in a political environment where municipalities are constantly challenged by global factors that constantly impact municipal operations (Mohale 2017:85). In a developmental state such as South Africa, government is expected to respond to both global and national factors. Municipalities are expected to adapt to economic challenges such as effects of COVID-19 by providing incentives to pay less on rates for the indigent people like the elderly, poor and young unemployed people. Expectedly, taxpayers serve as buffers by paying tax that is used to support the poverty alleviation strategies. Naidoo and Rampal (2019) assert that municipalities can adapt to micro environmental factors while being support by ward councillors and other stakeholders in processes such as the IDP and the Local Economic Development (LED). These stakeholders involve the municipal officials, government officials and experts, business fraternity, community leaders and voluntary community organisations or private sector companies.

\section{Stakeholders' engagement process in service delivery}

Stakeholders have a vested interest on the success the municipality in service provision and development. They include community members, municipalities, investors, suppliers, interest groups, non-governmental organisations, associations and traders. These are some of the steps that include stakeholders' involvement in service provision:

\section{- Develop a detailed communication plan}

The IDP guide municipalities to develop their plans by including all the resources and goods needed in a particular municipal jurisdiction (Van Der Waldt 2014). The plan must reflect all the various channels to connect all possible stakeholders to participate in the itemised plan (Ekung, Okonkwo \& Odesola 2014). These items can be useful in participatory budgeting and in the planning of public projects, where communities reflect their needs through identified appropriations:

- Create a conducive environment

It is significant for the ward councillors and other leaders to provide a conducive environment for stakeholders to participate in the issues affecting their municipality (Ekung et al. 2014). Stakeholders can participate well when they are briefed about the issues such as project goals and have all details at hand - the who, what, when, how and why. Clarity on responsible persons can also alleviate the fear of failure and can shed understanding of how the engagement will be unfolding amongst stakeholders:

- Interacting and communicating with stakeholders

A healthy communication between the stakeholders and the municipal officials is needed to provide services effectively and to implement the public project without excluding any stakeholder (Ngilambi \& McCubbin 2017). Managers and municipal officials must provide stakeholders the opportunity to contribute with inputs during service provision, especially in new projects and when there are changes needed. Stakeholders must be constantly briefed with new developments and be provided with all crucial information to assist them to perform their roles well, especially in the early stages of developing a service and a public project:

\section{- Monitoring and evaluation}

It has become a culture for all the public organisations to monitor and evaluate their services and goods they produce along the lines of the implementing policy or programme (Nelson 2016). Stakeholders are sometimes used as outside observers, yet they can contribute effectively if they can be invited to do so by the implementing departments and local municipalities. It is crucial to monitor and evaluate services to check on the success of the policies and the capability of the performing municipality of agency. 


\section{The study location}

The researcher chose eDumbe Local Municipality in Paulpietersburg to be the location of the study because one of the researchers is familiar with it and the villages within eDumbejurisdiction in KwaZulu-Natal Province. As eDumbe Local Municipality is a category B, it does not have full autonomy to make decisions as part of the Zululand district in the north-western part of the KwaZulu-Natal Province. eDumbe is situated within the area next to the Mpumalanga Province in the north. This municipality does not collect enough revenue to sustain its operations and services.

eDumbe Municipality has a population of about 89614 people. According to Statistics South Africa (SA) 2016, eDumbe has $41.3 \%$ of its population under the age of 15 years, whilst $54.2 \%$ of the population is aged between 15 and 65 years. It is a small municipality that is mostly rural with one town, Paulpietersburg.

The internal organisational structure of most organisations is based primarily on the arrangement and grouping of personnel to accomplish tasks. A strongly hierarchical structure, for instance, is characterised by 'ranks' in which superiors direct the actions of their subordinates towards the goals of the organisation. Individuals of a higher rank supervise and assign tasks to their subordinates. This structure supports the primary way tasks are accomplished that ultimately contribute to the goals of the organisation.

The eDumbe Municipality comprises eight wards, which are monitored by ward councillors. eDumbe tourist attraction is based on cultural tourism with many heritage sites including the residence and the grave of Mkabayi kaJama of the Zulu Nation at kwaGamakazi and the Voortrekker Park in Paulpietersburg. It is also rich in ecotourism with the existence of the Ithala Game Reserve, Pongola Bush Nature Reserve and Natal Spa Hot Springs and Leisure Resort (eDumbe Municipality, IDP 2019-20).

\section{Research method and procedures}

This study adopted a mixed research approach, where data were collected using both questionnaires and interviews. The rationale for using a mixed approach is to avoid the limitation of both qualitative and qualitative instruments during data collection (Makhoere, Jokonya \& Gorejena 2020). It can offer rich data because questionnaires were distributed to a large sample and interviews were also conducted (Maree 2019). The sample was drawn from eDumbe's population by recognising participants who were willing to participate and who understood the context of effective service delivery in eDumbe. A convenient sample was extracted from stakeholders who included municipal officials, employees at the mayor's office, the municipal manager, councillors, community leaders, representatives from the non-governmental organisations, civil society, government officials, community leaders, members of business fraternity and the residents of eDumbe that was directly and indirectly responsible for service delivery. The researcher used Excel and the thematic approach to analyse data.

\section{Data analysis and interpretation}

Data were collected from three villages, and all eight wards from these villages were considered for sampling. The researcher selected 160 participants to participate in this study from a community population of 101607 inhabitants. The researchers further considered a convenient sample to be appropriate for this study. According to Maree (2016), a convenient sampling is considerable fit for this study because of its ability of being incredibly, uncomplicated, prompt and economical. The questionnaires and the interview schedule were written in both English and isiZulu to accommodate all participants at eDumbe. To avoid bias when using the selected sample, the researchers remained truthful and honest in the whole process of the research conduct.

\section{Section A: Biographical data}

This section summarises the biographical characteristics of the respondents.

Table 1 demonstrates the gender distribution by age, and it can be reported that the ratios were distributed between within the range of 2:3 (41.9 and 55.5), respectively. Within the age category of $45-49$ years, 33.3 were male. Within the

TABLE 1: The overall gender distribution by age

\begin{tabular}{|c|c|c|c|c|c|}
\hline \multirow[t]{2}{*}{ Age } & \multirow[t]{2}{*}{ Variable } & \multicolumn{3}{|c|}{ Gender } & \multirow[t]{2}{*}{ Total } \\
\hline & & Male & Female & Other & \\
\hline \multirow[t]{4}{*}{$18-24$} & head-count & 20 & 30 & 0 & 50 \\
\hline & Within age & 40.0 & 60.0 & 0.0 & 100.0 \\
\hline & Within gender & 30.8 & 34.9 & 0.0 & 32.3 \\
\hline & Of total & 12.9 & 19.4 & 0.0 & 32.3 \\
\hline \multirow[t]{4}{*}{$25-29$} & Head-count & 3 & 13 & 1 & 17 \\
\hline & Within age & 17.6 & 76.5 & 5.9 & 100.0 \\
\hline & Within gender & 4.6 & 15.1 & 25.0 & 11.0 \\
\hline & Of total & 1.9 & 8.4 & 0.6 & 11.0 \\
\hline \multirow[t]{4}{*}{$30-34$} & Head-count & 12 & 10 & 1 & 23 \\
\hline & Within age & 52.2 & 43.5 & 4.3 & 100.0 \\
\hline & Within gender & 18.5 & 11.6 & 25.0 & 14.8 \\
\hline & Of total & 7.7 & 6.5 & 0.6 & 14.8 \\
\hline \multirow[t]{4}{*}{$35-39$} & Head-count & 12 & 5 & 0 & 17 \\
\hline & Within age & 70.6 & 29.4 & 0.0 & 100.0 \\
\hline & Within gender & 18.5 & 5.8 & 0.0 & 11.0 \\
\hline & Of total & 7.7 & 3.2 & 0.0 & 11.0 \\
\hline \multirow[t]{4}{*}{$40-44$} & Head-count & 10 & 9 & 2 & 21 \\
\hline & Within age & 47.6 & 42.9 & 9.5 & 100.0 \\
\hline & Within gender & 15.4 & 10.5 & 50.0 & 13.5 \\
\hline & Of total & 6.5 & 5.8 & 1.3 & 13.5 \\
\hline \multirow[t]{4}{*}{$45-49$} & Head-count & 4 & 8 & 0 & 12 \\
\hline & Within age & 33.3 & 66.7 & 0.0 & 100.0 \\
\hline & Within gender & 6.2 & 9.3 & 0.0 & 7.7 \\
\hline & Of total & 2.6 & 5.2 & 0.0 & 7.7 \\
\hline \multirow[t]{4}{*}{50 and above } & Head-count & 4 & 11 & 0 & 15 \\
\hline & Within age & 26.7 & 73.3 & 0.0 & 100.0 \\
\hline & Within gender & 6.2 & 12.8 & 0.0 & 9.7 \\
\hline & Of total & 2.6 & 7.1 & 0.0 & 9.7 \\
\hline \multirow[t]{4}{*}{ Total } & Head-count & 65 & 86 & 4 & 155 \\
\hline & Within age & 41.9 & 55.5 & 2.6 & 100.0 \\
\hline & Within gender & 100.0 & 100.0 & 100.0 & 100.0 \\
\hline & Of total & 41.9 & 55.5 & 2.6 & 100.0 \\
\hline
\end{tabular}

Source: Zwane, Z.M., 2017, 'An assessment of the efficiency and effectiveness of the management of service delivery: A case study of eDumbe Municipality', Doctoral thesis, University of KwaZulu-Natal, Westville Campus. 
category of males only, 6.2 were between the ages of 45 and 49 years. This category of males between the ages of 45 and 49 years formed 2.6 of the total sample.

Table 2 indicates the composition of participants according to race. There was a total of 94.3 black respondents as compared with a small proportion of 5.7 mixed race. eDumbe municipal area is more dominated by black residents, and there are very few white and Indian people living in the area. Black people and mixed-race people were the only ones who were willing to take part in this study.

Figure 1 presents a geographic location of eDumbe municipal jurisdiction of all the municipal area serviced by eDumbe municipality (www.municipalities.co.za).

Figure 2 presents the organisational structure of eDumbe municipality which imply that there are various units headed by officials ar eDumbe municipality (IDP, 2012-2017).

In Figure 3, participants obtained education such as primary education (19.7), secondary education (51), Diploma (10.8), Degree (12.1) and post-graduate (6.5). Many respondents are literate enough to understand and respond to the questions asked by researchers. This statistic is useful and reflects the authenticity about the fact that participants can engage municipal officials and other stakeholders in issues affecting them because they are literate. According to Marzuki (2015), when citizens possess education and local knowledge, they can propose innovative solutions that can address their problems and can lead to constructive resource allocation. Also, a fair proportion of the respondents with higher

TABLE 2: Racial representation of participants.

\begin{tabular}{lc}
\hline Race & Composition \\
\hline Black people & 94.3 \\
Mixed-race people & 5.7 \\
\hline
\end{tabular}

Source: Zwane, Z.M., 2017, 'An assessment of the efficiency and effectiveness of the management of service delivery: A case study of eDumbe Municipality', Doctoral thesis, University of KwaZulu-Natal, Westville Campus.

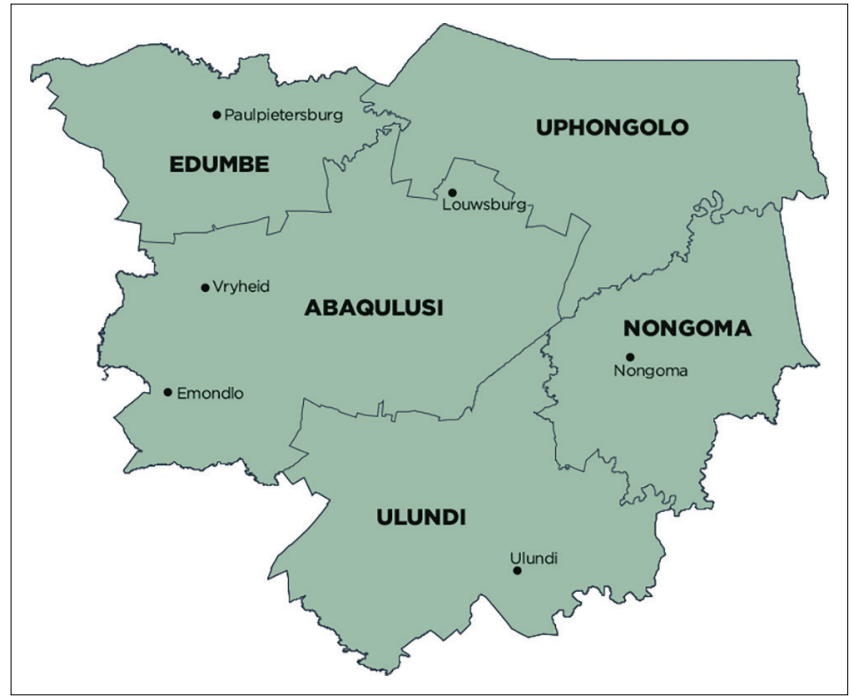

Source: municipalities.co.za (adopted from https://municipalities.co.za/map/1113/edumbe local-municipality)

FIGURE 1: eDumbe locality municipality map. qualification can contribute with high-level options during public participation.

\section{Section B: Responses from the empirical research}

The aim of this study was to assess the extent to which stakeholders and community participate in service provision at the eDumbe Municipality. Data were analysed and interpreted according to the following themes:

\section{Understanding of stakeholders participation}

When participants were probed to indicate whether they understand stakeholders' participation, 3.8\% of the respondents strongly agreed and $14 \%$ of them agreed to the question. In contrast, $24.8 \%$ disagreed and $21.7 \%$ strongly disagreed. Based on the interview transcripts, it surfaced that participants were dissatisfied with their involvement in decision-making and they were not timeously informed. They further indicated that the communication strategy used by the municipality was not suitable because it was regarded as ineffective or non-existent. One of the participants from the business fraternity, indicated that they have been called from the IDP and LED road shows. Most of the respondents (35.7) were neutral in their responses. It is important to observe that the public participation spectrum dictates the nature of

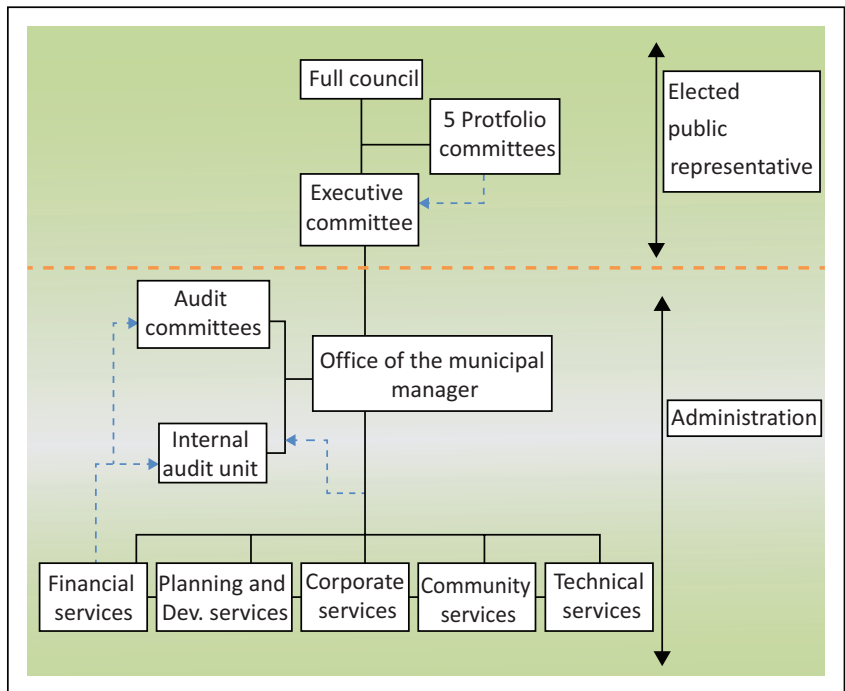

Source: sDumbe IDP (2012-2017)

FIGURE 2: Organisational chart (eDumbe Municipality).

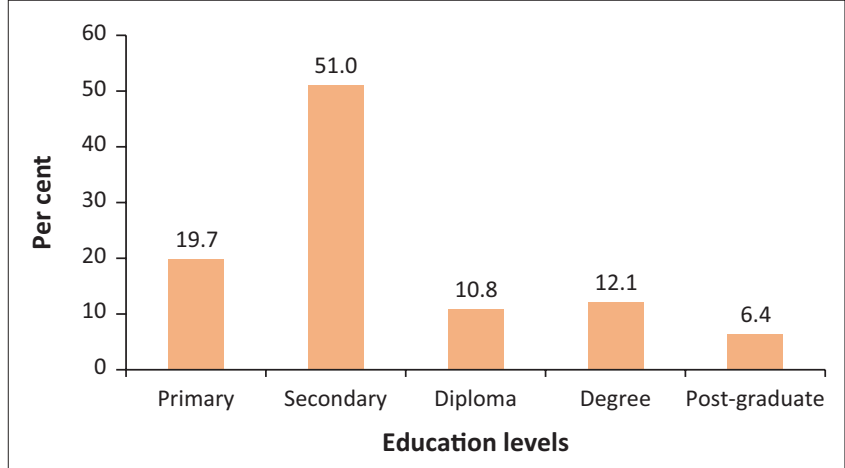

FIGURE 3: Education levels of the respondents. 
public participation levels at a given time. Hecker et al. (2019) are of the view that public participation is often misunderstood although it should be accepted as the involvement of stakeholders in development and implementation of policies that rely on public and scientific perceptions.

\section{Involvement of the stakeholders in planning for service delivery and development}

Stakeholders were probed about their involvement in the planning of services and development efforts at eDumbe. It has also been observed that stakeholders' have knowledge about the planning forums of IDP that took place in their communities although they had no direct involvement in the planning phase. A larger number of 43.6 respondents strongly agreed, while 16.7 agreed that municipality include the community in the planning of municipal services at eDumbe. This implies that some stakeholders are directly involved in the activities of the municipality that can shape their future. According to Zwane (2017:56), IDP and LED roadshows are conducted by eDumbe municipalities annually to prepare for resource allocation and budget estimates. Another participant agreed that a local newspaper often announces notices from municipality such as an invitation to attend a meeting but not all the residents from villages read the newspapers. $\mathrm{Ng}$ and Rahman (2021) asserted that it is crucial for stakeholders to use their knowledge and experience to participation in planning and development processes to promote long-term community involvement and development in communities. Few participants who play an important role in the development and service delivery at eDumbe make a difference in their lives and other people's lives. Some stakeholders prioritise their vested interest first before they can determine the success of their municipal engagement. Van Der Waldt (2017) pointed out clearly the importance of early involvement of stakeholders in planning of community resources to legitimatise the efforts of development and resource application in communities. Therefore, the municipal officials must inform the stakeholders that it is their right to be involved in planning for resources and service delivery because it affects them. In a democratic society, public participation is used as a ladder to create democratic spaces where stakeholders can communicate with each other and know the perceptions of the consumers and the ability of the municipalities to offer services. When there is a gap, there is dissatisfaction about government's provision and the potential performance of government officials and political office bearers.

\section{Tools and strategies for promoting stakeholder's participation}

The participants were asked whether they have been exposed to mechanisms that can improve their participation. Most of the participants were aware of public meetings, which are commonly used for public participation. They indicated that the mayor invites residents to attend 'imbizos' in their villages to report on service delivery and budget preparations that are allocated per their IDP process. The majority (32.55) of the respondents strongly agreed that there are forums to promote PP, and 29.3 agreed, respectively, to the statement. Other participants were not pleased with the fact that the municipality has mixed agenda of combining public participation with entertainment, which was popular in the communities. Another participant brought to light the fact that local government system does not operate in a vacuum, it is prominent to environmental changes that support municipality such as the central government, non-governmental sector, business people and political parties.

A smaller number of the respondents, $11.9 \%$ and $10.8 \%$, respectively, responded negatively. Whilst $15.9 \%$ of the respondents were neutral, and they indicated that they no longer have trust in the government.

\section{Providing information feedback to stakeholders}

Respondents were probed to rate the municipality's responsiveness in providing feedback to the stakeholders and communities. A minority of $9.6 \%$ respondents strongly agreed and $29.9 \%$ agreed to the statement. They indicated that residents do not bother attending public meeting where they can be briefed about how the municipality has escalated their needs and demands. During public meetings, stakeholders can also be empowered by the information distributed to them because these meetings are also used as a platform for empowerment and to enhance accountability from the municipal officials on how public money has been spent by municipalities. This is echoed by the low response of community members who participate in the activities of the municipality. Some participants from the community were dissatisfied with the way councillors interfered in the election of ward committee members where only members from their political party are elected (Fourie 2009). Ward councillors are expected to adhere to the South African Constitution (1996) mandated when they participate in the local government and elections even though they are in favour participatory democracy. A sizable number, $29.9 \%$, of the respondents, were neutral in their response, meaning that they were not participating in the entire process; $14.6 \%$ and $15.9 \%$ of the respondents disagreed and strongly disagreed to the statement. Public participation must involve follow-up visits to the stakeholders and the beneficiaries to determine the extent to which decisions are affecting the community members and to assess the level of impact of municipal decisions in service provision. It is also the responsibility of the municipalities and national government to monitor and evaluate the extent to which local needs are addressed through service delivery. Based on the responses of the participants, it seems as if that the process of empowering the stakeholders with information is not happening well because there are challenges within the process of participation for issues affecting their interests.

\section{Political leadership (councillors) and public participation}

Participants were probed on the involvement of political leaders and politicians in public participation. A noticeable number of $24.4 \%$ disagreed and $21.7 \%$ strongly disagreed with the statement. This is because councillors can change their 
mindset once they are elected and distance themselves from their constituency. Councillors are also responsible for attending their party's political activities, and they do not have enough time to serve the constituencies and tackle their problems immediately. The respondents also indicated that some officials and councillors always refer to their party mandates when they carry out their duties. It should be observed that political interference can be a challenge to community members who are not supporting a political idea; hence it is important that political ideas do not dominate in public participation. In most cases, when there are community meetings arranged to elect political deployees, the councillors interfere in the election process of ward committees. In that way, the ward committees are elected on party's political affiliation, which then defeats the purpose of having a ward committee. Molepo, Maleka and Khalo (2015) asserted that during public participation, it is not easy to separate politics from public participation because political office bearers would want to honour the interests of their political parties when they are on duty.

\section{Conclusions and recommendations}

This study demonstrated that stakeholders' participation in service delivery is crucial to support the sustainability of eDumbe Municipality even though the stakeholders are still challenged by various issues. Findings from this study suggest that one of the main challenges is shortage of financial and human resources that could sustain development and service delivery in that area of jurisdiction. Participatory democracy informs a legal provision of fair and equitable engagement of stakeholders, whilst municipal officials chose a lame duck approach to account and respond to the needs of their constituencies and communities. Municipal officials are also responsible for steer participatory democracy in a direction that suits them and the community and honour policy determinants such as 'Batho Pele' principles. Local government, as the third sphere of government that is closer to the people, is expected to continuously engage stakeholders in matters affecting them and ensure that representatives participate directly with the electorate. It is evident from the results of the study that the members of the community do not participate the way they should in the activities of the eDumbe Municipality. Lack of stakeholder participation emanate from various issues that include non-compliance, political interference and improper management of funds. This study indicated that there is a low level of stakeholder engagement at eDumbe municipal area, in service provision and in development projects and programmes. This might be caused by participants that do not reflect the aspirations and experiences of all stakeholders. In the absence of regular public meetings attended by stakeholders, there is minimal chances that stakeholder's participation can be fully realised in terms of the Municipal Systems Act.

\section{Recommendations}

It is therefore recommended that councillors and municipal officials must engage stakeholders in all the planning and processes that include service delivery and development at eDumbe municipal area. There is a need for a participatory empowerment approach in the training and awareness forums to empower residents with various methods and strategies used for engaging stakeholders at eDumbe.

Municipal officials must tap on the competencies of the residents and other stakeholders to advance development in the area and use their innovative skills and ideas effectively during public participation for the benefit of the people who live in those wards irrespective of political affiliation.

The office responsible for public participation at the eDumbe Municipality must be responsible for mentoring councillors and community leaders and create democratic spaces whether community issues are handled at grassroots level up to the council, by both public officials and community leaders, communities and political leaders.

The eDumbe Municipality, with the assistance of Cooperative Governance and Traditional Affairs (COGTA), must monitor and evaluate their programmes and projects continuously in areas of service provision.

There is a room for further study on sustainability as a mechanism to improve service delivery.

\section{Acknowledgements Competing interests}

The authors declare that they have no financial or personal relationships that may have inappropriately influenced them in writing this article.

\section{Authors' contributions}

Z.Z. collected primary data and N.S.M. collected secondary data , wrote and edited the article.

\section{Ethical considerations}

Ethical clearance to conduct this study was obtained from the University of KwaZulu-Natal Humanities \& Social Sciences Research Ethics Committee (No. HSS/0153/016D).

\section{Funding information}

This research received no specific grant from any funding agency in the public, commercial or not-for-profit sectors.

\section{Data availability}

Data sharing is not applicable to this article as no new data were created or analysed in this study.

\section{Disclaimer}

The views and opinions expressed in this article are those of the authors and do not necessarily reflect the official policy or position of any affiliated agency of the authors. 


\section{References}

Adu-Gyamfi, R., Asongu, S., Mmusi, T., Wamalwa, H. \& Mangori, M., 2020, A comparative study of export processing zones in the wake of sustainable development goals: Cases of Botswana, Kenya, Tanzania and Zimbabwe, Research Africa Network, WP/20/025.

Aiguosatile, O. \& Uyi, E.L., 2011, 'Local government administration and development: A survey of Oredo State, Nigeria', African Research Review 5(3), 148-156. https:// doi.org/10.4314/afrrev.v5i3.67348

Barber, B.R., 1994, 'Participatory democracy in health care: the role of the responsible citizen', New Jersey medicine: the journal of the Medical Society of New Jersey $91(7), 468-470$.

Bruce, R., 2020, 'Political wars in KwaZUlu-Natal', City Press, 21 September 2014, p. 1.

De Visser, J. \& Chigwata, T., 2020, 'Municipalities and COVID-19: A summary and perspective on the national disaster management directions', Local Government Bulletin 15(1), 1.

Du Plessis, D.J., 2014, 'A critical reflection on urban spatial planning practices and outcomes in post-apartheid South Africa', Urban Forum 25(1), 69-88. https://doi. org/10.1007/s12132-013-9201-5

Ekung, S.B., Okonkwo, E. \& Odesola, L., 2014, 'Factors influencing construction Stakeholders' engagement outcome in Nigeria', Sciences 20, 101-114. https://doi. org/10.18052/www.scipress.com/ILNS.20.101

Escobar, O., 2017, 'Pluralism and democratic participation: What kind of citizen are citizens invited to be?', Contemporary Pragmatism 14(2017), 416-438. https://doi.org/10.1163/18758185-01404002

Fourie, D., 2009, 'Institutional mechanisms and good governance: A perspective on the South African public sector', Journal of Public Administration 44(4), 1114-1123.

Fuo, O., 2017, 'Intrusion into the autonomy of South African local government: Advancing the minority judgment in the Merafong City case', De Jure Law Journal $50(2), 324-345$.

Hecker, S, Wicke, N., Haklay, M. \& Bonn, A., 2019, 'How does policy conceptualise citizen science? A qualitative content analysis of international policy documents', Citizen Science: Theory and Practice 4(1), 32. https://doi.org/10. 5334/cstp.230

Kaufman, A.S., 1960, 'Human nature and participatory democracy', NOMOS: American Society for Political and Legal Philosophy 3, 266.

Kgatle, M.S., 2018, 'Servant leadership: An urgent style for the current political leadership in South Africa', Verbum et Ecclesia 39(1), a1815. https://doi. org/10.4102/ve.v39i1.1815

Khaile, T.S., Davids, G.J. \& Khaile, F.T., 2021, 'Limitations of the principal-agent theory to explain the problem of non-compliance in South African municipalities', African Journal of Governance \& Development 10(1), 164-183.

Ledger, T., 2020, The logic of appropriateness: Understanding compliance in South African local government, Public Affairs Institute, Johannesburg.

Maree, K., 2019, First steps in research, 3rd edn., Van Schaik publishers, Pretoria.

Mabizela, H. \& Matsiliza, N.S., 2020, 'Uncovering the gaps in the provision of services in the rural Okhahlamba Municipality of KwaZulu-Natal province', Africa's Public Service Delivery and Performance Review 8(1), a390. https://doi.org/10.4102/ apsdpr.v8i1.390

Makhoere, C.T.E., Jokonya, O. \& Gorejena, K., 2020, 'Assessing the Impact of Personal Mobile Device in Higher Educational Enviroment: The case of Sol Plaatjie University', in 2020 2nd International Multidisciplinary Information Technology and Engineering Conference (IMITEC), pp. 1-7, IEEE.
Marzuki, A., 2015, 'Challenges in the Public Participation and the Decision Making Process', Sociologija i prostor/Sociology \& Space 53(1).

Masuku, M. \& Jili, N., 2019, 'Public service delivery in South Africa: The political influence at local government level', Journal of Public Affairs 19(4), e1935. https:// doi.org/10.1002/pa.1935

Modise, L.J., 2017, 'The notion of participatory democracy in relation to local ward committees: The distribution of power', In die Skriflig 51(1), a2248. https://doi org/10.4102/ids.v51i1.2248

Mohale, D., 2017, 'Developmental local government as a catalyst or an impediment towards a South African developmental state', Master's degree dissertation, University of the Witwatersrand, Johannesburg.

Molepo, J.N, Maleka, M.C. \& Khalo, T., 2015, 'Public participation and service delivery: The case of the city of Tshwane', Journal of Public Administration 50(2), 345-369.

Mugisha, S., 2007, 'Effects of incentive applications on technical efficiencies: Empirical evidence from Ugandan water utilities', Utilities Policy 15(4), 225-233.

Municipality, Z.L., 2019, Integrated Development Planning, eDumbe Loca Municipality, South Africa.

Naidoo, C. \& Ramphal, R.R., 2018, 'The factors that affect public participation for effective municipal service delivery: A case of ward committees', South African Journal of Industrial Engineering 29(4), 82-93.

Nelson, C., 2016, 'Exploring monitoring and evaluation within a good governance perspective: A case study of Stellenbosch municipality', Thesis (MPA), Stellenbosch University.

Ng, S.K. \& Rahman, S., 2021, 'Conceptualising governance approach on stakeholders participation and collaboration in George Town Festival, Penang, Malaysia', Earth
and Environmental Science 799(2021), 012016. https://doi.org/10.1088/1755and Environmental

Ngilambi, S.K. \& McCubbin, C.N., 2017, 'Local action with international cooperation to improve and sustain water, sanitation and hygiene services towards effective improve and sustain water, sanitation and hygiene services towards effective process in Afghanistan', in 40th WEDC International conference, Loughborough.

Ogonu, C.G., Nwokah, G.N. \& Acee-Eke, B.C., 2019, 'Procedural justice and customer post-complaint behaviour in fast food firms in Port Harcourt, Nigeria', American Journal of Industrial and Business Management 9(2), 385-402. https://doi. org/10.4236/ajibm.2019.92026

Pasquini, L. \& Shearing, L., 2014, 'Municipalities, politics, and climate change: An example of the process of institutionalizing an environmental agenda within loca government', Journal of Environment and Development 23(2), 271-296. https:// doi.org/10.1177/1070496514525406

Republic of South Africa, 1996, Constitution of the Republic of South Africa (Act 108 of 1996), Government Printers, Pretoria.

Republic of South Africa, 1999, Public Financial Management Act (Act no. 1 of 1999), National Treasury, Pretoria.

Van der Waldt, C., 2014, 'The statutory and regulatory framework for local government', in G. Van der Waldt (eds.), Municipal management: Serving the people, 2 nd edn., Juta, Kenwyn.

Van der Waldt, G., 2017, 'Local government', in C. Landsberg \& S. Graham (eds.) Government and politics in South Africa, 5th edn., Van Schaik, Pretoria.

Wangari, M., 2018, 'Procedural justice in service delivery', Master's degree dissertation, University of Nairobi.

Wolfe, J.D., 1985, 'A defence of participatory democracy', The Review of Politics 47(3), 370-389. https://doi.org/10.1017/S0034670500036925

Zwane, Z.M., 2017, 'An assessment of the efficiency and effectiveness of the management of service delivery: A case study of eDumbe Municipality', Doctoral thesis, University of KwaZulu-Natal, Westville Campus. 